\title{
PPARY2 Pro12Ala polymorphism was associated with favorable cardiometabolic risk profile in HIV/HCV coinfected patients: a cross-sectional study
}

Pilar García-Broncano1', Juan Berenguer ${ }^{2,3}$, Amanda Fernández-Rodríguez ${ }^{1}$, Daniel Pineda-Tenor ${ }^{1}$, María Ángeles Jiménez-Sousa', Mónica García-Alvarez , Pilar Miralles², Teresa Aldámiz-Echevarria²,3, Juan Carlos López ${ }^{2}$, Dariela Micheloud ${ }^{4}$ and Salvador Resino ${ }^{1 *}$

\begin{abstract}
Background: Peroxisome proliferator-activated receptor gamma-2 gene (PPARY2) rs1801282 (Pro12Ala) polymorphism has been associated with lower risk of metabolic disturbance and atherosclerosis. The aim of this study was to analyze the association between the Pro12Ala polymorphism and cardiometabolic risk factors in human immunodeficiency virus (HIV)/Hepatitis C virus (HCV)-coinfected patients.

Methods: We carried out a cross-sectional study on 257 HIV/HCV coinfected patients. PPARY2 polymorphism was genotyped by GoldenGate ${ }^{\oplus}$ assay. The main outcome measures were: i) serum lipids (cholesterol, triglycerides, high-density lipoprotein (HDL-C), low-density lipoprotein (LDL-C), LDL-C/HDL-C, and atherogenic index (AI)); ii) homeostatic model assessment (HOMA-IR) values; iii) serum adipokines (leptin, adiponectin, resistin, plasminogen activator inhibitor-1(PAI-1), hepatic growth factor (HGF), and nerve growth factor (NGF)). Generalized Linear Models (GLM) with gamma distribution (log-link) were used to investigate the association between PPARY2 polymorphism and continuous outcome variables. This test gives the differences between groups and the arithmetic mean ratio (AMR) in continuous outcome variables between groups.
\end{abstract}

Results: The rs 1801282 CG/GG genotype was associated with low values of cholesterol (adjusted arithmetic mean ratio $(\mathrm{aAMR})=0.87(95 \%$ of confidence interval $(95 \% \mathrm{Cl})=0.79 ; 0.96) ; \mathrm{p}=0.004)$ and $\mathrm{LDL}-\mathrm{C}(\mathrm{aAMR}=0.79(95 \% \mathrm{Cl}=0.68 ; 0.93)$; $\mathrm{p}=0.004)$. Furthermore, rs $1801282 \mathrm{CG} / \mathrm{GG}$ was associated with low values of HOMA-IR (aAMR $=0.69(95 \% \mathrm{Cl}=0.49$; 0.98); $p=0.038$ ) among patients with significant liver fibrosis ( $F \geq 2$ ). Moreover, rs1801282 CG/GG was also associated with low serum values of hepatic growth factor (HGF) (aAMR $=0.61(95 \% \mathrm{Cl}=0.39 ; 0.94) ; p=0.028)$, and nerve growth factor (NGF) (aAMR $=0.47(95 \% \mathrm{Cl}=0.26 ; 0.84) ; p=0.010)$. The serum levels of leptin, adiponectin, resistin, and PAl-1 did not show significant differences.

Conclusions: The presence of PPARY2 rs1801282 G allele (Ala variant) was associated with a protective cardiometabolic risk profile versus CC genotype in HIV/HCV-coinfected patients. Thus, PPARY2 rs1801282 polymorphism may play a significant role in the development of metabolic disorders in HIV/HCV coinfected patients, and might have an influence on the cardiovascular risk.

Keywords: HIV/HCV coinfection, Serum lipids, Adipokines, Insulin resistance, Fibrosis, Single nucleotide polymorphism

\footnotetext{
* Correspondence: sresino@isciii.es

'Unidad de Infección Viral e Inmunidad, Centro Nacional de Microbiología, Instituto de Salud Carlos III, Carretera Majadahonda- Pozuelo, Km 2.2,

Majadahonda, Madrid 28220, Spain

Full list of author information is available at the end of the article
} 


\section{Background}

The introduction of effective combination antiretroviral therapy (cART) has dramatically reduced the mortality and illness related to human immunodeficiency virus (HIV) infection [1]. However, an increased risk of dyslipidemia, insulin resistance, and type 2 diabetes mellitus (T2DM) has been described in human immunodeficiency virus (HIV)-infected individuals who underwent cART [2]. Furthermore, HIV/hepatitis $\mathrm{C}$ virus $(\mathrm{HCV})$ coinfection is associated with metabolic disturbance such as dyslipidemia, insulin resistance, and T2DM, which are also associated with an increased risk of cardiovascular disease [3]. These series of factors have increased the risk of cardiovascular diseases in patients with $\mathrm{HIV} / \mathrm{HCV}$ coinfection in cART era $[4,5]$.

Peroxisome proliferator-activated receptor gamma (PPAR $\gamma$ ) is considered as a "key element" in the course of glucose homeostasis, lipoprotein metabolism and vascular homeostasis [6]. The most common polymorphism in PPARy2 gene is the Pro12Ala (rs1801282) polymorphism, which generates a cytosine-guanine exchange (CCA-to-GCA missense mutation), affecting the $\mathrm{NH} 2$-terminal residue that defines the adipocyte-specific PPAR 2 isoform [7]. The rs1801282 G allele (which encodes Ala) has been associated with lower risk of insulin resistance and T2DM $[8,9]$, hypertension [10], and lower value of carotid artery intima-media thickness, protecting against early atherosclerosis [11-15]. Additionally, rs1801282 polymorphism seems to have an influence on blood lipid levels in different ways, according to the lipid fraction analyzed [16]. However, it has not been found an association between Pro12Ala (rs1801282) polymorphism and metabolic syndrome [17]. In clinical trials with large numbers of patients, the effect of Pro12Ala polymorphism on metabolic disturbances remains controversial since Ala variant has been related to unfavorable changes in serum cholesterol [18], no improvement in lipid variables [19], improvement of plasma lipid levels [20], decreased risk of developing hyperglycemia [21], increased BMI, waist-tohip ratio, and fasting glucose [22], and weight loss [23]. In the Spanish population, the Ala12 allele was associated with lower total triglycerides levels and increased insulin sensitivity [24].

Probably, Pro12Ala polymorphism may act differently in HIV/HCV coinfected patients due to the fact that HIV proteins and antiretroviral drugs seem to negatively influence the adipocyte PPARy expression [25-28]. Besides, $\mathrm{HIV} / \mathrm{HCV}$ coinfected patients have an intrinsic metabolic deregulation, which may be enhanced by unhealthy habits that are very pronounced in people coinfected with HIV and HCV (smoking, drug abuse, alcohol, etc.) [29]. Thus, the aim of our study was to analyze the association between the Pro12Ala polymorphism and cardiometabolic risk in $\mathrm{HIV} / \mathrm{HCV}$ coinfected patients.

\section{Patients and methods \\ Patients}

We carried out a cross-sectional study in $\mathrm{HIV} / \mathrm{HCV}$ coinfected patients from Hospital Gregorio Marañón (Madrid, Spain) between September 2000 and July 2009. The study was approved by the Institutional Review Board and the Research Ethic Committee ("Comité de Ética de la Investigación y de Bienestar Animal") of the Instituto de Salud Carlos III. This study was conducted in accordance with the Declaration of Helsinki and patients gave their written consent for the study. All patients were European whites.

All subjects were $\mathrm{HCV}$ treatment-naive patients who were potential candidates for HCV therapy and, in most cases, underwent a liver biopsy. The inclusion criteria were: detectable HCV-RNA by polymerase chain reaction, negative hepatitis $B$ surface antigen, availability of DNA sample, no clinical evidence of hepatic decompensation, no diabetes mellitus, and stable cART or no need for cART. Patients with active opportunistic infections, active drug and/or alcohol addiction, and other concomitant diseases were excluded.

A total of $293 \mathrm{HIV} / \mathrm{HCV}$ coinfected patients met the inclusion criteria, but only 257 patients were available for analysis: 11 patients were excluded due to genotyping problems and 25 were discarded due to missing data (no homeostatic model assessment (HOMA-IR) data $(\mathrm{n}=23)$ and no lipid data $(n=2))$. Besides, only 207 patients had liver biopsy data and 109 patients had an available sample stored at $-80^{\circ} \mathrm{C}$ for testing serum adipokines.

\section{Epidemiological and clinical data}

Medical records were used to obtain epidemiological and clinical data when HCV therapy was started and/or liver biopsy was performed.

The duration of HCV infection for patients with a history of intravenous drug use was estimated starting from the first year they shared needles and other injection paraphernalia, which are the most relevant risk practices for $\mathrm{HCV}$ transmission [30]. For non-intravenous drug use patients, we only included those patients for which the initiation of their HCV infection could be determined with certainty.

Biochemistry panel was measured using a fully automated clinical chemistry analyzer (Hitachi 912, Boehringer Mannheim, Germany) in serum of fasting patients. The collected data were total cholesterol (TC), triglycerides (TG) and high-density lipoprotein (HDL-C). The low-density lipoprotein (LDL-C) was calculated by Friedewald estimation (LDL-C = TC - HDL-C - (TG/5)) [31]. The atherogenic risk was estimated for each patient using the atherogenic index (AI) $(\mathrm{AI}=(\mathrm{TC}-\mathrm{HDL}-\mathrm{C}) / \mathrm{HDL}-\mathrm{C})$. Non HDL-C was calculated as TC minus HDL-C. The degree of IR was estimated for each patient using the HOMA-IR method 
described by Matthews et al. [32]: fasting glucose ( $\mathrm{mmol} / \mathrm{l})$ times fasting insulin ( $\mathrm{mU} / \mathrm{l})$ divided by 22.5 .

Liver biopsies were performed as previously described [33]. Liver fibrosis was estimated according to Metavir score. Fibrosis was scored as follows: F0, no fibrosis; F1, portal fibrosis; F2, periportal fibrosis or rare portalportal septa; F3, fibrous septa with architectural distortion; no obvious cirrhosis (bridging fibrosis); and F4, definite cirrhosis.

\section{Laboratory assays}

Serum adipokines (leptin, adiponectin, resistin, plasminogen activator inhibitor-1 (PAI-1), hepatic growth factor (HGF), and nerve growth factor (NGF)) were measured by multiplex assay using Multiplex kit (LINCOplex ${ }^{\mathrm{mm}}$; LINCO Research, St. Charles, Missouri, United States) in the Luminex $100^{\text {mix }}$ analyzer (Luminex Corporation, Austin, Texas, United States), following manufacturer's specifications.

Genomic DNA was extracted from peripheral blood with Qiagen kit (QIAamp DNA Blood Midi/Maxi; Qiagen, Hilden, Germany). DNA samples were genotyped at the Spanish National Genotyping Center (CeGen; http://www. cegen.org/) for the rs1801282 (C>G) SNP at PPAR 2 gene. Genotyping was performed by using GoldenGate ${ }^{\circ}$ assay with VeraCode ${ }^{\bullet}$ Technology (Illumina Inc. San Diego, CA, USA). Moreover, we have also considered other two SNPs that have recently been associated with metabolic disturbances in $\mathrm{HIV} / \mathrm{HCV}$ coinfected patients: SLC30A8 rs13266634 [34] and ADIPOQ rs2241766 [35]. These SNPs were selected from a review of Staiger et al. about the T2DM risk genes and their genetic variants in patients not infected with HIV and/ or HCV [36].

\section{Outcome variables}

i. Dyslipidemia: Serum concentration of TC, TG, HDL-C, LDL-C, LDL-C/HDL-C, and AI.

ii. Insulin resistance: HOMA-IR values.

iii. Serum adipokines: levels of leptin, adiponectin, resistin, PAI-1, HGF, and NGF.

\section{Statistical analysis}

All statistical tests were performed with the Statistical Package for the Social Sciences (SPSS) 19.0 software (IBM Corp., Chicago, USA). All p-values were two-tailed and statistical significance was defined as $\mathrm{p}<0.05$.

For the description of the study population, p-values were estimated with nonparametric tests: Mann-Whitney $\mathrm{U}$ test was used for continuous variable and Chi-square test for categorical variable.

For the genetic association study, the analysis was carried out according to a dominant genetic model of $\mathrm{G}$ allele (CC vs. CG/GG), which was the model that best fit to our data. Univariate and multivariate Generalized Linear
Models (GLM) with gamma distribution (log-link) were used to investigate the association between PPAR 2 polymorphism and continuous outcome variables. This test gives the differences between groups and the arithmetic mean ratio (AMR) in continuous outcome variables between groups. All GLM tests were adjusted by the most important clinical and epidemiological characteristics. We included the SNP (Enter algorithm) and the most relevant epidemiological and clinical characteristics (backward criterion with a p-value for exit of 0.20). The covariables used were gender, age, body mass index (BMI), acquired immune deficiency syndrome, nadir CD4+ T-cells, undetectable HIV viral load ( $<50$ copies $/ \mathrm{mL}$ ), time with cART, cART with protease inhibitor, specific antiretroviral drugs (saquinavir, efavirenz, ritonavir, tenofovir, thymidine analogues (AZT, d4T), etc.), HCV genotype, HCV viral load $\geq 500,000 \mathrm{IU} / \mathrm{ml}$, SLC3OA8 rs13266634 and ADIPOQ rs2241766 polymorphisms.

\section{Results}

\section{Study population}

Table 1 shows the main epidemiological and clinical characteristics of the 257 non-diabetic HIV/HCV-coinfected patients (191 men and 66 women).

The frequency of CG/GG genotype (Ala variant) in our dataset was $13.2 \%$, and was in accordance with minimum allele frequency (MAF) listed on the NCBI SNP database, where the frequency for CG/GG genotypes ranged from $12 \%$ to $25 \%$ (http://www.ncbi.nlm.nih.gov/projects/SNP/ snp_ref.cgi?rs=1801282). PPAR 2 polymorphism was in Hardy-Weinberg equilibrium $(\mathrm{p}>0.05)$ and displayed less than $5 \%$ of missing values.

\section{PPARY2 polymorphism and lipid profile}

Patients with rs 1801282 CG/GG genotype (Ala variant) had lower values of TC $(p=0.008)$, LDL-C $(p=0.005)$, LDL-C/ HDL-C ratio $(\mathrm{p}=0.027)$, and AI $(\mathrm{p}=0.031)$ than $\mathrm{rs} 1801282$ CC (Pro variant) carriers (Table 2). Furthermore, Ala variant was associated with low values of TC (adjusted AMR $(\mathrm{aAMR})=0.87 \quad((95 \%$ of confidence interval $(95 \% \mathrm{CI})=$ $0.79 ; 0.95) ; \mathrm{p}=0.004)$ and LDL-C $(\mathrm{aAMR}=0.79(95 \% \mathrm{CI}=$ $0.68 ; 0.93) ; \mathrm{p}=0.004$ ) (Table 2). Moreover, we evaluated the cut-offs for serum lipids ( $\mathrm{TC} \geq 200 \mathrm{mg} / \mathrm{dL}, \mathrm{TG} \geq$ $170 \mathrm{mg} / \mathrm{dL}, \quad \mathrm{LDL}-\mathrm{C} \geq 100 \mathrm{mg} / \mathrm{dL}, \mathrm{HDL}-\mathrm{C} \leq 35 \mathrm{mg} / \mathrm{dL}$, LDL-C/HDL-C $\geq 3.0$, and AI $\geq 3.5$ ), but no statistically significant results were found (data not shown).

\section{PPARY2 polymorphism and insulin resistance}

Patients with rs1801282 CG/GG genotype had similar HOMA-IR values than patients with rs1801282 CC genotype (Table 3). However, when patients were stratified by liver fibrosis $(\mathrm{F}<2$ vs. $\mathrm{F} \geq 2)$, rs1801282 CG/GG patients with significant fibrosis $(\mathrm{F} \geq 2)$ had lower HOMA-IR values than rs1801282 CC carriers $(\mathrm{p}=0.025)$ (Table 3$)$. 
Table 1 Clinical and epidemiological characteristics of all HIV/HCV coinfected patients stratified by PPARY2 genotype

\begin{tabular}{|c|c|c|c|c|}
\hline & & PPARY2 polymo & & \\
\hline & All patients $(n=257)$ & $C C(n=223)$ & CG/GG $(n=34)$ & $\mathrm{p}$-value \\
\hline Gender (male) & $191(74.3 \%)$ & $165(74.0 \%)$ & $26(76.5 \%)$ & 0.758 \\
\hline Age (years) & $40.9(37.9 ; 44.7)$ & $41.0(37.9 ; 44.7)$ & $40.1(36.0 ; 44.7)$ & 0.675 \\
\hline BMI (kg/m2) & $22.5(20.9 ; 24.7)$ & $22.5(20.9 ; 24.7)$ & $22.6(20.7 ; 24.3)$ & 0.875 \\
\hline $\mathrm{BMI} \geq 25 \mathrm{~kg} / \mathrm{m} 2$ & $60(23.4 \%)$ & $54(23.9 \%)$ & $7(20.6 \%)$ & 0.674 \\
\hline HIV acquired by IVDU & $219\left(85 \_.2 \%\right)$ & $191(85.7 \%)$ & $28(82.4 \%)$ & 0.785 \\
\hline Years since HCV infection & $21.3(16.6 ; 24.4)$ & $21.6(16.7 ; 24.6)$ & $18.5(16.1 ; 23.3)$ & 0.149 \\
\hline Prior AIDS & $74(28.8 \%)$ & $64(28.7 \%)$ & 10 (29.4\%) & 0.973 \\
\hline CART & 215 (83.7\%) & $186(83.4 \%)$ & $29(85.3 \%)$ & 0.831 \\
\hline Time on cART (years) & $4.8(2.9 ; 7.8)$ & $4.7(2.7 ; 7.7)$ & $4.9(3.3 ; 8.7)$ & 0.490 \\
\hline Current cART protocols & & & & \\
\hline Any NRTIs + any PI & $62(24.1 \%)$ & $51(22.9 \%)$ & $11(32.4 \%)$ & 0.229 \\
\hline Any NRTIs + PI + NNRTI & $3(1.2 \%)$ & $2(0.9 \%)$ & $1(2.9 \%)$ & 0.301 \\
\hline Any NRTIs + any NNRTI & $130(50.6 \%)$ & $114(51.1 \%)$ & $16(47.1 \%)$ & 0.659 \\
\hline Only NRTIs & $20(7.8 \%)$ & 19 (8.5\%) & $1(2.9 \%)$ & 0.258 \\
\hline Specific antiretroviral drugs & & & & \\
\hline Zidovudine & $71(7.6 \%)$ & $63(28.8 \%)$ & $8(23.5 \%)$ & 0.566 \\
\hline Stavudine & $66(25.7 \%)$ & $55(25.4 \%)$ & $11(32.4 \%)$ & 0.339 \\
\hline Didanosine & $41(16.0 \%)$ & $35(15.7 \%)$ & $6(17.6 \%)$ & 0.772 \\
\hline Tenofovir & $70(27.2 \%)$ & $59(26.5 \%)$ & $11(32.4 \%)$ & 0.472 \\
\hline Abacavir & $43(16.7 \%)$ & $41(18.4 \%)$ & $2(5.9 \%)$ & 0.069 \\
\hline Efavirenz & $76(29.6 \%)$ & $72(32.3 \%)$ & $4(11.8 \%)$ & 0.015 \\
\hline Ritonavir & $47(18.3 \%)$ & $38(17.0 \%)$ & $9(26.5 \%)$ & 0.185 \\
\hline HIV markers & & & & \\
\hline Nadir CD4+ T-cells (cells/ $\mu \mathrm{L}$ ) & $208(93 ; 314.5)$ & $195(92.5 ; 306)$ & $257(145 ; 364)$ & 0.176 \\
\hline CD4+ T cells $/ \mu \mathrm{L}$ & $467(341.7 ; 670.7)$ & $467(340 ; 660)$ & $471(368 ; 690)$ & 0.678 \\
\hline HIV-RNA $<50$ copies $/ \mathrm{mL}$ & $76.6 \%(196 / 256)$ & $77.5 \%(172 / 222)$ & $70.6 \%(24 / 34)$ & 0.377 \\
\hline HCV markers & & & & \\
\hline HCV-genotype $1 / 4$ & $72.7 \%(181 / 249)$ & $72.1 \%(155 / 215)$ & $76.5 \%(26 / 34)$ & 0.594 \\
\hline HCV-RNA $\geq 500,000 \mathrm{UI} / \mathrm{ml}$ & $75.6 \%(186 / 246)$ & $74.5 \%(158 / 212)$ & $82.4 \%(28 / 34)$ & 0.324 \\
\hline Significant fibrosis $(F \geq 2)$ & $47.8 \%(99 / 207)$ & $46.7 \%(85 / 182)$ & $56.0 \%(14 / 25)$ & 0.383 \\
\hline
\end{tabular}

Categorical variables are expressed in percentage (absolute count). Continuous variables are expressed in median (percentile 25; percentile 75). P-values were estimated with nonparametric Mann-Whitney $U$ test for continuous variable and Chi-square test for categorical variable.

Abbreviations: AIDS acquired immunodeficiency syndrome, BMI body mass index, CART combination antiretroviral therapy, HCV hepatitis C virus, HCV-RNA HCV plasma viral load, HIV human immunodeficiency virus, HIV-RNA HIV plasma viral load, IVDU intravenous drug users, NNRTI no nucleoside analog reverse-transcriptase inhibitors, NRTI nucleoside analog reverse-transcriptase inhibitors, PI protease inhibitors.

When adjusted GLM analysis was performed among patients with significant liver fibrosis $(\mathrm{F} \geq 2)$, Ala variant was associated with low values of HOMA-IR (aAMR $=0.69$ (95\% CI $=0.49 ; 0.98) ; \mathrm{p}=0.038$ ) (Table 3). Moreover, no statistically significant results were found for the cutoffs of HOMA-IR ( $\geq 2.0, \geq 2.5, \geq 3.0$, and $\geq 3.8$ ) (data not shown).

PPARy2 polymorphism and serum adipokine levels Rs1801282 CG/GG carriers had lower values of HGF $(\mathrm{p}=0.003)$ and NGF $(\mathrm{p}=0.008)$ than rs1801282 CC (Ala variant) carriers (Table 4). When adjusted GLM analysis was performed, Ala variant was associated with low values of $\mathrm{HGF}(\mathrm{AMR}=0.61(95 \% \mathrm{CI}=0.39 ; 0.94) ; \mathrm{p}=$ $0.028)$, and NGF (AMR $=0.47(95 \% \mathrm{CI}=0.26 ; 0.84) ; \mathrm{p}=$ 0.010) (Table 4). However, we did not find any significant association for adiponectin, leptin, PAI-1, and resistin levels (Table 4).

\section{Discussion}

In this pilot study, rs $1801282 \mathrm{G}$ allele (Ala variant) was related to favorable cardiometabolic risk profile with lower 
Table 2 Association between PPARY2 CG/GG genotype (Ala variant) and serum lipids in HIV/HCV coinfected patients

\begin{tabular}{llllll}
\hline & CC & CG/GG & p-value & aAMR (95\% Cl) & p-value \\
\hline TC $(\mathrm{mg} / \mathrm{dL})$ & $156.0(63.0)$ & $139.0(49.0)$ & $\mathbf{0 . 0 0 8}$ & $0.87(0.79 ; 0.95)$ & $\mathbf{0 . 0 0 4}$ \\
$\mathrm{TG}(\mathrm{mg} / \mathrm{dL})$ & $122.0(49.0)$ & $122.0(27.0)$ & 0.319 & $0.92(0.81 ; 1.04)$ & 0.163 \\
$\mathrm{LDL}-\mathrm{C}(\mathrm{mg} / \mathrm{dL})$ & $86.4(54.1)$ & $72.4(36.0)$ & $\mathbf{0 . 0 0 5}$ & $0.79(0.68 ; 0.93)$ & $\mathbf{0 . 0 0 4}$ \\
$\mathrm{HDL}-\mathrm{C}(\mathrm{mg} / \mathrm{dL})$ & $36.0(18.0)$ & $36.0(12.0)$ & 0.921 & $0.98(0.89 ; 1.09)$ & 0.734 \\
$\mathrm{LDL}-\mathrm{C} / \mathrm{HDL}-\mathrm{C}$ & $2.1(1.3)$ & $1.8(1.1)$ & $\mathbf{0 . 0 2 7}$ & $0.86(0.73 ; 1.01)$ & 0.067 \\
$\mathrm{Al}$ & $2.7(1.6)$ & $2.5(1.4)$ & $\mathbf{0 . 0 3 1}$ & $0.87(0.76 ; 1.01)$ & 0.069 \\
\hline
\end{tabular}

Values expressed as median [interquartile range = upper quartile (Q3) - lower quartile (Q1)] and adjusted arithmetic mean ratio (aAMR) [95\% of confidence interval $(95 \% \mathrm{Cl})$ ]. Statistically significant differences are shown in bold. ${ }^{(a)}$ P-values were calculated by generalized linear models (GLM) with gamma distribution (log-link). ${ }^{(b)}$ P-values were calculated by GLM with log-link adjusted by the most important clinical and epidemiological characteristics (see Statistical analysis section). Abbreviations: HCV hepatitis C virus, HIV human immunodeficiency virus, TC total cholesterol, TG triglycerides, LDL-C low density lipoprotein, HDL-C high density lipoprotein, LDL-C/HDL-C ratio of low density lipoprotein/high density lipoprotein, Al atherogenic index.

levels of serum lipids (TC and LDL-C), HOMA-IR among patients with significant fibrosis $(\mathrm{F} \geq 2)$, and adipokines (HGF and NGF). However, no significant association was found between rs1801282 polymorphism and metabolic disturbance (serum lipids and HOMA-IR values higher than cut-offs).

A recent meta-analysis has shown an inconclusive association between rs1801282 polymorphism and lipid profile in HIV seronegative subjects [16]. This meta-analysis suggests that, compared with rs1801282 CC genotype, carriers of rs1801282 CG/GG genotype have significant increased blood TC, and marginally significant increased blood HDL-C in healthy male subjects [16]. Moreover, there are only three articles published about PPAR 2 rs1801282 polymorphism in HIV infection [37-39], which did not find any association of rs1801282 polymorphism with lipodystrophy, lipid profile, and insulin sensitivity in HIV-1-infected patients treated with cART [37-39]. In our $\mathrm{HIV} / \mathrm{HCV}$ coinfected patients, Ala variant carriers had lower values of TC, LDL-C, LDL-C/HDL-C, and AI. In fact, the severe dyslipidemia in these patients may be affected by a large number of factors such as chronic hepatitis C, HIV infection itself, cART used, and body composition changes [29], as well as the traditional factors that increase atherosclerotic risk in the non-HIV-infected population, including genetic factors, diet, alcohol, obesity and inactivity. In our study, it seems clear the protective effect PPAR 2 Ala variant on serum lipids, being able to have a long-term protective effect on associated cardiovascular disease. In this regard, PPAR 2 Ala variant has been associated with a reduced risk of hypertension [10], early atherosclerosis [12-15], coronary artery disease [40], and myocardial infarction [41] in general population.

The majority of published data in non HIV-infected patients indicate the association of Ala variant with reduced rates of insulin resistance and T2DM [8,9], although this effect is influenced by genetic heterogeneity [42]. In our study, we only found this favorable effect of Ala variant in patients with significant fibrosis $(F \geq 2)$, who had the lowest HOMA-IR values. Since approximately $50 \%$ of portal insulin is cleared by the liver during first-past transit [43], liver fibrosis might lead to impaired hepatic clearance of insulin and, consequently, it could affect HOMA-IR values. Therefore, rs1801282 polymorphism might play an important role on alterations in insulin metabolism secondary to significant fibrosis. However, the PPAR 2 rs1801282 polymorphism was not associated with the HOMA-IR cutoffs that indicate IR. This lack of significance might be due to the limited number of patients used in the stratified analysis, or also to the possible distortive effect of direct and indirect factors related to both HIV and HCV infections, and cART [29]. Moreover, we must also take in mind that our patients had a relatively low BMI $(22.5 \mathrm{~kg} / \mathrm{m} 2)$, possibly due to the fact that around $85 \%$ of our patients were IDUs. HIV infection and chronic drug abuse both compromise nutritional status of patients despite major advances in the HIV treatment [44], allowing that HIV-positive IDUs had lower BMI.

PPAR $\gamma$ is involved in the regulation of adipogenesis, lipid storage, and glucose metabolism [7]. The adipose

Table 3 Association between PPARY2 CG/GG genotype (Ala variant) and HOMA-IR in HIV/HCV coinfected patients

\begin{tabular}{llllll}
\hline & CC & CG/GG & p-value $^{(\mathbf{a})}$ & aAMR (95\% Cl) & p-value ${ }^{(\mathbf{b})}$ \\
\hline All patients & $2.1(2.4)$ & $1.7(2.3)$ & 0.839 & $0.89(0.66 ; 1.20)$ & 0.452 \\
Patients with $\mathrm{F}<2$ & $1.8(1.8)$ & $1.3(1.5)$ & 0.681 & $1.01(0.61 ; 1.65)$ & 0.988 \\
Patients with $\mathrm{F} \geq 2$ & $2.5(3.3)$ & $2.3(1.9)$ & $\mathbf{0 . 0 2 5}$ & $0.69(0.49 ; 0.98)$ & $\mathbf{0 . 0 3 8}$
\end{tabular}

Values expressed as median [interquartile range = upper quartile (Q3) - lower quartile (Q1)] and adjusted arithmetic mean ratio (aAMR) [95\% of confidence interval $(95 \% \mathrm{Cl})]$. Statistically significant differences are shown in bold. ${ }^{(a)}$ P-values were calculated by generalized linear models (GLM) with gamma distribution (log-link). (b) P-values were calculated by GLM with log-link adjusted by the most important clinical and epidemiological characteristics (see Statistical analysis section). Abbreviations: HCV hepatitis C virus, HIV human immunodeficiency virus, HOMA homeostatic model assessment. 
Table 4 Association between PPARY2 CG/GG genotype (Ala variant) and serum adipokines in HIV/HCV coinfected patients

\begin{tabular}{llllll}
\hline & CC & CG/GG & p-value $^{(\mathbf{a})}$ & aAMR (95\% CI) & p-value \\
\hline HGF $(\mathrm{pg} / \mathrm{mL})$ & $1964.9(2079.2)$ & $1044.4(1327.1)$ & $\mathbf{0 . 0 0 3}$ & $0.61(0.39 ; 0.94)$ & $\mathbf{0 . 0 2 8}$ \\
NGF $(\mathrm{pg} / \mathrm{mL})$ & $9.48(9.43)$ & $6.16(8.32)$ & $\mathbf{0 . 0 0 8}$ & $0.47(0.26 ; 0.84)$ & $\mathbf{0 . 0 1 0}$ \\
PAI-1 $(\mathrm{pg} / \mathrm{mL})$ & $1474.9(17338.2)$ & $1363.1(7366.9)$ & 0.721 & $0.783(0.36 ; 1.69)$ & 0.534 \\
Leptin $(\mathrm{pg} / \mathrm{mL})$ & $3438.1(154050.1)$ & $5547.6(22928.2)$ & 0.529 & $0.93(0.55 ; 1.58)$ & 0.795 \\
Resistin $(\mathrm{pg} / \mathrm{mL})$ & $1233.1(15063.9)$ & $1070.4(2795.7)$ & 0.478 & $0.76(0.39 ; 1.47)$ & 0.425 \\
Adiponectin $(\mathrm{ng} / \mathrm{mL})$ & $662.9(10917.3)$ & $1226.6(4993.1)$ & 0.634 & $1.14(0.39 ; 3.31)$ & 0.800 \\
\hline
\end{tabular}

Values expressed as median [interquartile range = upper quartile (Q3) - lower quartile (Q1)] and adjusted arithmetic mean ratio (aAMR) [95\% of confidence interval $(95 \% \mathrm{Cl})$ ]. Statistically significant differences are shown in bold. ${ }^{(a)} \mathrm{P}$-values were calculated by generalized linear models (GLM) with gamma distribution (log-link). ${ }^{(b)}$ P-values were calculated by GLM with log-link adjusted by the most important clinical and epidemiological characteristics (see Statistical analysis section). Abbreviations: HCV hepatitis C virus, HIV human immunodeficiency virus, HGF hepatic growth factor, NGF nerve growth factor, PAI-1 plasminogen activator inhibitor-1.

tissues release a number of adipokines, that may influence on insulin sensitivity and lipid metabolism [45,46], which are regulated directly or indirectly by PPAR 2 [47]. The exact mechanism by which the rs1801282 polymorphism acts is not well understood, but Ala variant at PPAR 2 gene seems to be an important modulator in metabolic control in the body [7]. In this respect, Ala variant at $P P A R \gamma 2$ gene seems to reduce transcriptional activity of $P P A R \gamma 2$ gene, resulting in lower transcription levels of genes activated by PPAR $\gamma 2$ and decreasing the process of inflammation and cardiovascular disease [10,12-15]. In addition, the functional effect of rs1801282 evaluated in silico has shown that the Alanine variant may affect protein function [48]. Therefore, PPAR 2 rs1801282 polymorphism could affect the adipokines delivery, since an increase in PPARY gene expression generates the up-regulation of the insulin-sensitizing factor (adiponectin) and down-regulation of insulin-resistant factor (leptin and TNF- $\alpha$ ) [47], as well as, a less efficient stimulation of PPAR $\gamma$ activated genes predisposing people to lower levels of adipose tissue mass accumulation [49].

Metabolic disorders are closely related to chronic inflammatory response, characterized by abnormal adipokine production, and the activation of proinflammatory signaling pathways, which may play a central role in the cardiovascular pathophysiology [50]. The HGF and NGF are considered adipokines with a possible link to metabolic disorders and other inflammatory-related diseases. HGF and NGF blood levels are elevated in obese subjects and are associated with the presence of metabolic syndrome and T2DM, and both molecules have been described as an inflammatory response protein made by adipocytes [51]. HGF expression, in adipose tissue, is inhibited by NF- $\mathrm{kB}$ through suppression of PPAR $\gamma$ function in the HGF gene promoter and PPAR- $\gamma$ agonists induce HGF expression [52]. In addition, PPAR- $\gamma$ agonists may also induce NGF expression [53]. In our study, the presence of rs1801282 CG/GG genotype was associated with low serum levels of HGF and NGF, possibly due to the effect of Ala variant on the decreased expression of $P P A R \gamma 2$ gene, which decrease the process of inflammation and cardiovascular disease [10,12-15]. HGF is a powerful mitogen for hepatocytes and other epithelial tissues mainly produced by perivascular fat cells [54], and plays a special role because it is both a very potent angiogenic growth factor and a cytokine involved in hematopoiesis and vasculogenesis [55,56]. In addition, NGF is a small soluble protein (neurotrophin) that is secreted by various tissues in the body, and it promotes the growth of nerve cell processes and survival of neurons [57]. NGF seems to play a role in several diseases related to cardiovascular risk, such as coronary atherosclerosis, obesity, T2DM, and metabolic syndrome [58].

We have used the same cohort to publish several genetic association studies between SNPs and metabolic disturbances. The SNPs were selected from a review of Staiger et al. about the type 2 diabetes risk genes and their genetic variants in patients not infected with HIV and/or HCV [36], and our approach was to evaluate whether these SNPs also might be markers of metabolic alterations in $\mathrm{HIV} / \mathrm{HCV}$ coinfected population. Therefore, although we have performed multiple tests, we have not conducted a random search of a meaningful result because these SNPs have been evaluated in general population [36]. Thus, these results should not be affected by adjusting the "p-value" after multiple tests because our study was a clinical-orientated study $[59,60]$.

There are also other issues that have to be considered for a correct interpretation of our data. First, this is a cross-sectional study with a limited number of patients, which could limit achieving statistically significant values. Secondly, metabolic disturbance may be caused by several interacting genetic and environmental determinants, being complicated to find the true individual effects of each disease-associated factor. In this regard, we did not have data on some extra factors that may influence on lipid levels and insulin resistance such as exercise habits, diet, lipodystrophy, and alcohol intake. Thirdly, our study 
should have been also performed in $\mathrm{HCV}$-monoinfected patients in order to evaluate the significance of only chronic hepatitis $\mathrm{C}$, and in HIV-monoinfected patients in order to evaluate the significance of HIV infection and cART in the development of metabolic disturbances. Fourthly, cART may increase the risk for unfavorable cardiometabolic profile [2]; but in our study, cART characteristics were included in the adjusted regression analyses (see Statistical analysis section). Furthermore, the number of patients taking efavirenz in the rs $1801282 \mathrm{CC}$ group was significantly higher than that in the rs1801282 CG/GG group; but we did not find any significant associations among lipid levels and HOMA-IR values with efavirenz (data not shown). Fifthly, the patients selected for our study were patients who met a set of criteria for starting HCV treatment and it is possible that this may have introduced a selection bias.

\section{Conclusions}

The presence of rs1801282 G allele (Ala variant) was related to a protective cardiometabolic risk profile in HIV/ HCV coinfected patients. Thus, PPAR 2 rs1801282 polymorphism may play a significant role in the development of metabolic disorders in HIV/HCV coinfected patients, and might have an influence on the cardiovascular risk. However, we consider that further analyses are needed in order to determine the potential use of rs1801282 polymorphism as a marker of cardiovascular risk in HIV/ HCV-coinfected patients.

\section{Meetings at which parts of the data were presented}

Some parts have been presented in the $21^{\text {th }}$ Conference on Retroviruses and Opportunistic Infections (CROI): GarcíaBroncano P, Berenguer J, Fernández-Rodríguez A, PinedaTenor D, Jiménez-Sousa MA, Cosín J, García-Álvarez M, Miralles P, Aldámiz-Echevarria T, López JC , Micheloud D, Resino S. Pro12Ala Polymorphism Is Associated with Metabolic Disturbance in HIV/HCV Coinfected Patients. 21th Conference on Retroviruses and Opportunistic Infections (CROI 2014). Boston, Massachusetts, USA. March 3-6, 2014.

\footnotetext{
Abbreviations

AMR: Arithmetic mean ratio; Al: Atherogenic index; BMI: Body mass index; CART: Combination antiretroviral therapy; HGF: Hepatic growth factor; HCV: Hepatitis C virus; HDL-C: High-density lipoprotein; HOMA-IR: Homeostatic model assessment of insulin resistance; HIV: Human immunodeficiency virus; LDL-C: Low-density lipoprotein; NGF: Nerve growth factor; PAl-1: Plasminogen activator inhibitor-1; PPARY: Proliferator-activated receptor gamma; TC: Total cholesterol; TG: Triglycerides; T2DM: Type 2 diabetes mellitus.
}

\section{Competing interests}

The authors declare that they have no competing interests.

\section{Authors' contributions}

PGB performed statistical analysis, interpretation of the data and drafting the manuscript. JB participated in the study concept and design, patient selection, and acquisition of data. AFR participated in sample preparation, DNA isolation and genotyping pre-procedure, and contributed with critical revision of the manuscript. DPT participated in statistical analysis, interpretation of the data and drafting the manuscript. MAJS contributed with critical revision of the manuscript for important intellectual content. MGA participated in sample preparation, DNA isolation and genotyping pre-procedure. PM participated in patient selection, collection of samples and acquisition of data. TAE participated in patient selection, collection of samples and acquisition of data. JCL participated in patient selection and acquisition of data. DM participated in collection of samples and acquisition of data. SR participated in the study concept and design, statistical analysis, interpretation of the data and drafting the manuscript. All authors read and approved the final manuscript.

\section{Acknowledgements}

The authors wish to thank the Spanish National Genotyping Center (CeGen) for providing the genotyping services (http://www.cegen.org). We also acknowledge the patients in this study for their participation.

\section{Funding/support}

Funding/Support: This work has been supported by grants given by Fondo de Investigación de Sanidad en España (FIS) [Spanish Health Founds for Research] [grant numbers PI08/0738, Pl11/00245; PI08/0928, and PI1 1/01556], and "Fundación para la Investigación y la Prevención del Sida en España" (FIPSE) [grant number 361020/10]. This work has been (partially) funded by the RD12/0017/0024 and RD12/0017/0004 projects as part of the Plan Nacional R+D + I and cofinanced by ISCIII-Subdirección General de Evaluación y el Fondo Europeo de Desarrollo Regional (FEDER).

JB is an investigator from the Programa de Intensificación de la Actividad Investigadora en el Sistema Nacional de Salud (I3SNS), Refs INT10/009 and INT12/154. PGB, AFR, DPT, MAJS and MGA are supported by "Instituto de Salud Carlos III" [grant numbers Fl12/00036, UIPY-1377/08, CM12/00043, CD13/00013 and CD12/00442, respectively].

\section{Author details}

'Unidad de Infección Viral e Inmunidad, Centro Nacional de Microbiología, Instituto de Salud Carlos III, Carretera Majadahonda- Pozuelo, Km 2.2, Majadahonda, Madrid 28220, Spain. ${ }^{2}$ Unidad de Enfermedades Infecciosas/ VIH, Hospital General Universitario "Gregorio Marañón", Madrid 28007, Spain. ${ }^{3}$ Instituto de Investigación Sanitaria Gregorio Marañón (IISGM), Madrid 28007, Spain. ${ }^{4}$ Servicio de Medicina Interna, Hospital General Universitario "Gregorio Marañón", Madrid 28007, Spain.

Received: 22 June 2014 Accepted: 20 August 2014

Published: 27 August 2014

\section{References}

1. Bhaskaran KHO, Sannes M, Boufassa F, Johnson AM, Lambert PC, Porter K, CASCADE Collaboration: Changes in the risk of death after HIV seroconversion compared with mortality in the general population. JAMA 2008, 300:51-59. doi:10.1001/jama.1300.1001.1051.

2. Stanley TL, Grinspoon SK: Body composition and metabolic changes in HIV-infected patients. J Infect Dis 2012, 205(Suppl 3):S383-S390.

3. Younossi ZM, Stepanova M, Nader F, Younossi Z, Elsheikh E: Associations of chronic hepatitis C with metabolic and cardiac outcomes. Aliment Pharmacol Ther 2013, 37:647-652.

4. Gillis J, Smieja M, Cescon A, Rourke SB, Burchell AN, Cooper C, Raboud JM: Risk of cardiovascular disease associated with HCV and HBV co-infection among antiretroviral-treated HIV-infected individuals. Antivir Ther 2014, 19:309-317.

5. Bedimo R, Westfall AO, Mugavero M, Drechsler H, Khanna N, Saag M: Hepatitis C virus coinfection and the risk of cardiovascular disease among HIV-infected patients. HIV Med 2010, 11:462-468.

6. Wahli W, Michalik L: PPARs at the crossroads of lipid signaling and inflammation. Trends Endocrinol Metab 2012, 23:351-363.

7. Jeninga EH, Gurnell M, Kalkhoven E: Functional implications of genetic variation in human PPARgamma. Trends Endocrinol Metab 2009, 20:380-387.

8. Huguenin GV, Rosa G: The Ala allele in the PPAR-gamma2 gene is associated with reduced risk of type 2 diabetes mellitus in Caucasians and improved insulin sensitivity in overweight subjects. Br J Nutr 2010, 104:488-497. 
9. Gouda HN, Sagoo GS, Harding AH, Yates J, Sandhu MS, Higgins JP: The association between the peroxisome proliferator-activated receptor-gamma2 (PPARG2) Pro12Ala gene variant and type 2 diabetes mellitus: a HuGE review and meta-analysis. Am J Epidemiol 2010, 171:645-655.

10. Wang Y, Liu C: Quantitative evaluation of common polymorphism (rs1801282) in the PPARgamma2 gene and hypertension susceptibility. Gene 2012, 502:159-162.

11. Wu Z, Lou Y, Jin W, Liu Y, Lu L, Lu G: The Pro12Ala polymorphism in the peroxisome proliferator-activated receptor gamma-2 gene (PPARgamma2) is associated with increased risk of coronary artery disease: a meta-analysis. PLoS One 2012, 7:e53105.

12. Temelkova-Kurktschiev T, Hanefeld M, Chinetti G, Zawadzki C, Haulon S, Kubaszek A, Koehler C, Leonhardt W, Staels B, Laakso M: Ala12Ala genotype of the peroxisome proliferator-activated receptor gamma2 protects against atherosclerosis. J Clin Endocrinol Metab 2004, 89:4238-4242.

13. Iwata E, Yamamoto I, Motomura T, Tsubakimori S, Nohnen S, Ohmoto M, Igarashi T, Azuma J: The association of Pro12Ala polymorphism in PPARgamma2 with lower carotid artery IMT in Japanese. Diabetes Res Clin Pract 2003, 62:55-59.

14. Galgani A, Valdes A, Erlich HA, Mano C, Cheng S, Petrone A, Sentinelli F, Berni A, Baroni MG, Buzzetti R: Homozygosity for the Ala allele of the PPARgamma2 Pro12Ala polymorphism is associated with reduced risk of coronary artery disease. Dis Markers 2010, 29:259-264.

15. Al-Shali KZ, House AA, Hanley AJ, Khan HM, Harris SB, Zinman B, Mamakeesick M, Fenster A, Spence JD, Hegele RA: Genetic variation in PPARG encoding peroxisome proliferator-activated receptor gamma associated with carotid atherosclerosis. Stroke 2004, 35:2036-2040.

16. Huang $X$, Zhao J, Zhao T: Effects of peroxisome proliferator activated receptor-gamma 2 gene Pro12Ala polymorphism on fasting blood lipids: a meta-analysis. Atherosclerosis 2011, 215:136-144.

17. Zhang R, Wang J, Yang R, Sun J, Chen R, Luo H, Liu D, Cai D: Effects of Pro12Ala polymorphism in peroxisome proliferator-activated receptorgamma2 gene on metabolic syndrome risk: a meta-analysis. Gene 2014, 535:79-87.

18. Itariu BK, Zeyda M, Hochbrugger EE, Neuhofer A, Prager G, Schindler K, Bohdjalian A, Mascher D, Vangala S, Schranz M, Krebs M, Bischof MG, Stulnig TM: Long-chain n-3 PUFAs reduce adipose tissue and systemic inflammation in severely obese nondiabetic patients: a randomized controlled trial. Am J Clin Nutr 2012, 96:1137-1149.

19. Curti ML, Rogero MM, Baltar VT, Barros CR, Siqueira-Catania A, Ferreira SR: FTO T/A and peroxisome proliferator-activated receptor-gamma Pro12Ala polymorphisms but not ApoA1-75 are associated with better response to lifestyle intervention in Brazilians at high cardiometabolic risk. Metab Syndr Relat Disord 2013, 11:169-176.

20. AlSaleh A, Sanders TA, O'Dell SD: Effect of interaction between PPARG, PPARA and ADIPOQ gene variants and dietary fatty acids on plasma lipid profile and adiponectin concentration in a large intervention study. Proc Nutr Soc 2012, 71:141-153.

21. Jaziri R, Lobbens $S$, Aubert R, Pean F, Lahmidi S, Vaxillaire M, Porchay I, Bellili N, Tichet J, Balkau B, Froguel P, Marre M, Fumeron F: The PPARG Pro12Ala polymorphism is associated with a decreased risk of developing hyperglycemia over 6 years and combines with the effect of the APM1 G-11391A single nucleotide polymorphism: the Data From an Epidemiological Study on the Insulin Resistance Syndrome (DESIR) study. Diabetes 2006, 55:1157-1162.

22. Ramirez-Salazar M, Perez-Luque E, Fajardo-Araujo M, Garza SM, Malacara JM: Effect of the Pro12Ala polymorphism of the PPAR gamma 2 gene on response to pioglitazone treatment in menopausal women. Menopause 2008, 15:1151-1156.

23. Franks PW, Jablonski KA, Delahanty L, Hanson RL, Kahn SE, Altshuler D, Knowler WC, Florez JC: The Pro12Ala variant at the peroxisome proliferator-activated receptor gamma gene and change in obesity-related traits in the Diabetes Prevention Program. Diabetologia 2007, 50:2451-2460.

24. González Sánchez JLSRM, Fernández Perez C, Laakso M, Martínez Larrad MT: Effect of the Pro12Ala polymorphism of the peroxisome proliferator-activated receptor gamma-2 gene on adiposity, insulin sensitivity and lipid profile in the Spanish population. Eur J Endocrinol 2002, 147:495-501.

25. Otake K, Omoto S, Yamamoto T, Okuyama H, Okada H, Okada N, Kawai M, Saksena NK, Fujii YR: HIV-1 Nef protein in the nucleus influences adipogenesis as well as viral transcription through the peroxisome proliferator-activated receptors. AIDS 2004, 18:189-198.

26. Shrivastav S, Kino T, Cunningham T, Ichijo T, Schubert U, Heinklein P, Chrousos GP, Kopp JB: Human immunodeficiency virus (HIV)-1 viral protein $\mathrm{R}$ suppresses transcriptional activity of peroxisome proliferator-activated receptor \{gamma\} and inhibits adipocyte differentiation: implications for HIV-associated lipodystrophy. Mol Endocrinol 2008, 22:234-247.

27. Diaz-Delfin J, Domingo P, Mateo MG, Gutierrez Mdel M, Domingo JC, Giralt M, Villarroya F: Effects of rilpivirine on human adipocyte differentiation, gene expression, and release of adipokines and cytokines. Antimicrob Agents Chemother 2012, 56:3369-3375.

28. Mencarelli A, Francisci D, Renga B, D'Amore C, Cipriani S, Basile F, Schiaroli E, Baldelli F, Fiorucci S: Ritonavir-induced lipoatrophy and dyslipidaemia is reversed by the anti-inflammatory drug leflunomide in a PPAR-gammadependent manner. Antivir Ther 2012, 17:669-678.

29. Kotler DP: Hepatitis C, human immunodeficiency virus and metabolic syndrome: interactions. Liver Int 2009, 29(Suppl 2):38-46.

30. Thorpe LE, Ouellet LJ, Hershow R, Bailey SL, Williams IT, Williamson J, Monterroso ER, Garfein RS: Risk of hepatitis C virus infection among young adult injection drug users who share injection equipment. Am J Epidemiol 2002, 155:645-653.

31. Friedewald WT, Levy Rl, Fredrickson DS: Estimation of the concentration of low-density lipoprotein cholesterol in plasma, without use of the preparative ultracentrifuge. Clin Chem 1972, 18:499-502

32. Matthews DR, Hosker JP, Rudenski AS, Naylor BA, Treacher DF, Turner RC: Homeostasis model assessment: insulin resistance and beta-cell function from fasting plasma glucose and insulin concentrations in man. Diabetologia 1985, 28:412-419.

33. Berenguer J, Bellon JM, Miralles P, Alvarez E, Sanchez-Conde M, Cosin J, Lopez JC, Alvarez F, Catalan P, Resino S: Identification of liver fibrosis in HIV/HCV-coinfected patients using a simple predictive model based on routine laboratory data. J Viral Hepat 2007, 14:859-869.

34. Pineda-Tenor D, Micheloud D, Berenguer J, Jimenez-Sousa MA, FernandezRodriguez A, Garcia-Broncano P, Guzman-Fulgencio M, Diez C, Bellon JM, Carrero A, Aldamiz-Echevarria T, Garcia-Alvarez M, Resino S: SLC30A8 rs13266634 polymorphism is related to a favorable cardiometabolic lipid profile in HIV/hepatitis C virus-coinfected patients. AIDS 2014, 28:1325-1332.

35. Pineda-Tenor D, Berenguer J, Garcia-Broncano P, Jimenez-Sousa MA, Fernandez-Rodriguez A, Diez C, Garcia-Alvarez M, Carrero A, Catalan P, Aldamiz-Echevarria T, Resino S: Association of adiponectin (ADIPOQ) rs2241766 polymorphism and dyslipidemia in HIV/HCV-coinfected patients. Eur J Clin Invest 2014, 44:453-462.

36. Staiger $\mathrm{H}$, Machicao F, Fritsche A, Haring $\mathrm{HU}$ : Pathomechanisms of type 2 diabetes genes. Endocr Rev 2009, 30:557-585.

37. Saumoy M, Veloso S, Alonso-Villaverde C, Domingo P, Chacon MR, Miranda M, Aragones G, Gutierrez MM, Vilades C, Peraire J, Sirvent JJ, Lopez-Dupla M, Aguilar C, Richart C, Vidal F: PPARgamma Pro12Ala polymorphism in HIV-1-infected patients with HAART-related lipodystrophy. Curr HIV Res 2009, 7:533-540.

38. Hung YP, Lee NY, Lin SH, Chang HC, Wu CJ, Chang CM, Chen PL, Lin HJ, Wu YH, Tsai PJ, Tsai YS, Ko WC: Effects of PPARgamma and RBP4 gene variants on metabolic syndrome in HIV-infected patients with anti-retroviral therapy. PLoS One 2012, 7:e49102.

39. Nazih H, Raffi F, Taieb A, Reynes J, Choutet P, Cassuto JP, Ferry T, Chene G, Leport C, Bard JM: Peroxisome proliferator activating receptor alpha and gamma polymorphisms and metabolic abnormalities in HIV-infected patients receiving highly active antiretroviral therapy: the ANRS CO8 APROCO-COPILOTE study. AIDS Res Hum Retroviruses 2012, 28:393-399.

40. Regieli JJ, Jukema JW, Doevendans PA, Zwinderman AH, van der Graaf Y, Kastelein JJ, Grobbee DE: PPAR gamma variant influences angiographic outcome and 10-year cardiovascular risk in male symptomatic coronary artery disease patients. Diabetes Care 2009, 32:839-844.

41. Doney AS, Fischer B, Leese G, Morris AD, Palmer CN: Cardiovascular risk in type 2 diabetes is associated with variation at the PPARG locus: a Go-DARTS study. Arterioscler Thromb Vasc Biol 2004, 24:2403-2407.

42. Ludovico O, Pellegrini F, Di Paola R, Minenna A, Mastroianno S, Cardellini M, Marini MA, Andreozzi F, Vaccaro O, Sesti G, Trischitta V: Heterogeneous effect of peroxisome proliferator-activated receptor gamma2 Ala12 variant on type 2 diabetes risk. Obesity (Silver Spring) 2007, 15:1076-1081. 
43. Duckworth WC: Insulin degradation: mechanisms, products, and significance. Endocr Rev 1988, 9:319-345.

44. Hendricks EJ, Rothman RB, Greenway FL: How physician obesity specialists use drugs to treat obesity. Obesity (Silver Spring) 2009, 17:1730-1735.

45. Gougeon ML, Penicaud L, Fromenty B, Leclercq P, Viard JP, Capeau J: Adipocytes targets and actors in the pathogenesis of HIV-associated lipodystrophy and metabolic alterations. Antivir Ther 2004, 9:161-177.

46. Samaras K: Metabolic consequences and therapeutic options in highly active antiretroviral therapy in human immunodeficiency virus-1 infection. J Antimicrob Chemother 2008, 61:238-245.

47. Saraf N, Sharma PK, Mondal SC, Garg VK, Singh AK: Role of PPARg2 transcription factor in thiazolidinedione-induced insulin sensitization. J Pharm Pharmacol 2012, 64:161-171.

48. Cheng YC, Hsiao FC, Yeh EC, Lin WJ, Tang CY, Tseng HC, Wu HT, Liu CK, Chen CC, Chen YT, Yao A: VarioWatch: providing large-scale and comprehensive annotations on human genomic variants in the next generation sequencing era. Nucleic Acids Res 2012, 40:W76-W81.

49. Montagner A, Rando G, Degueurce G, Leuenberger N, Michalik L, Wahli W: New insights into the role of PPARs. Prostaglandins Leukot Essent Fatty Acids 2011, 85:235-243.

50. Fuentes E, Fuentes F, Vilahur G, Badimon L, Palomo I: Mechanisms of chronic state of inflammation as mediators that link obese adipose tissue and metabolic syndrome. Mediators Inflamm 2013, 2013:136584.

51. Fain JN: Release of interleukins and other inflammatory cytokines by human adipose tissue is enhanced in obesity and primarily due to the nonfat cells. Vitam Horm 2006, 74:443-477.

52. Yin J, Lee JH, Zhang J, Gao Z, Polotsky VY, Ye J: Regulation of hepatocyte growth factor expression by NF-kappaB and PPARgamma in adipose tissue. Am J Physiol Endocrinol Metab 2014, 306:E929-E936.

53. Meng B, Zhang Q, Huang C, Zhang HT, Tang T, Yang HL: Effects of a single dose of methylprednisolone versus three doses of rosiglitazone on nerve growth factor levels after spinal cord injury. J Int Med Res 2011, 39:805-814.

54. Rittig K, Dolderer JH, Balletshofer B, Machann J, Schick F, Meile T, Kuper M, Stock UA, Staiger H, Machicao F, Schaller HE, Konigsrainer A, Haring HU, Siegel-Axel DI: The secretion pattern of perivascular fat cells is different from that of subcutaneous and visceral fat cells. Diabetologia 2012, 55:1514-1525.

55. Nakagami H, Kaneda Y, Ogihara T, Morishita R: Hepatocyte growth factor as potential cardiovascular therapy. Expert Rev Cardiovasc Ther 2005, 3:513-519.

56. Bell LN, Cai L, Johnstone BH, Traktuev DO, March KL, Considine RV: A central role for hepatocyte growth factor in adipose tissue angiogenesis. Am J Physiol Endocrinol Metab 2008, 294:E336-E344.

57. Manni L, Rocco ML, Bianchi P, Soligo M, Guaragna M, Barbaro SP, Aloe L: Nerve growth factor: basic studies and possible therapeutic applications. Growth Factors 2013, 31:115-122.

58. Bullo M, Peeraully MR, Trayhurn P, Folch J, Salas-Salvado J: Circulating nerve growth factor levels in relation to obesity and the metabolic syndrome in women. Eur J Endocrinol 2007, 157:303-310.

59. Perneger TV: What's wrong with Bonferroni adjustments. BMJ 1998, 316:1236-1238.

60. Sterne JA, Davey Smith G: Sifting the evidence-what's wrong with significance tests? BMJ 2001, 322:226-231.

\section{doi:10.1186/s12967-014-0235-9}

Cite this article as: García-Broncano et al:: PPARY2 Pro12Ala

polymorphism was associated with favorable cardiometabolic risk profile in HIV/HCV coinfected patients: a cross-sectional study. Journal of Translational Medicine 2014 12:235.

\section{Submit your next manuscript to BioMed Central and take full advantage of:}

- Convenient online submission

- Thorough peer review

- No space constraints or color figure charges

- Immediate publication on acceptance

- Inclusion in PubMed, CAS, Scopus and Google Scholar

- Research which is freely available for redistribution

Submit your manuscript at www.biomedcentral.com/submit 